\begin{tabular}{llrr}
\hline \hline Volume: & 2 & E-ISSN: & $2655-1942$ \\
Number: & 2 & Terbitan: & November 2019 \\
Page : & $233-245$ & & \\
\hline
\end{tabular}

\title{
Pasar Modal Syariah dalam Tinjauan Al Maqoshid Syariah
}

\author{
Muhyidin \\ Fakultas Hukum, Universitas Diponegoro \\ Email: muhyidin85@yahoo.com
}

\begin{abstract}
Abstrak
Lembaga pasar modal secara umum, mempunyai permasalahan hukum, terutama unsur gharar (spekulatif), untuk mengatasinya maka lembaga pasar modal syariah didirikan. Artikel ini bertujuan menilai operasional pasar modal syariah, apakah secara pasti dapat menghilangkan unsur gharar dalam praktek di lapangan, serta bagaimana mekanisme yang dilakukan untuk maksud tersebut. Artikel ini merupakan kajian yang bersifat yuridis normatif dengan menggunakan pendekatan historis dan filosofis, dianalisis menggunakan teori maqashid syariah. Berdasarkan kajian yang dilakukan, disimpulkan bahwa pendirian pasar modal syariah telah menunjukkan upaya signifikan dalam menghilangkan unsur gharar dalam operasionalnya. Adanya mekanisme bahwa semua sekuritas yang memasuki aliran pasar modal syariah melalui seleksi ketat Syariah Islam JII (Jakarta Islamic Index) sekarang menjadi Indeks Saham Syariah Indonesia (ISSI) juga membantu untuk operasional dalam pasar modal syariah. Lembaga ini merupakan prasyarat, sekuritas Islam dengan bisnis utama yang tidak bertentangan dengan hukum Islam.
\end{abstract}

Kata kunci: Pasar Modal Syariah, Hukum Islam, Maqoshid syariah

\begin{abstract}
Capital market institutions in general, have legal problems, especially the element of gharar (speculative), to overcome this, the Islamic capital market institutions are established. This article aims to assess the operation of the Islamic capital market, whether it can eliminate the element of gharar in practice in the field, as well as how the mechanism is carried out for this purpose. This article is a normative juridical study using historical and philosophical approaches, analyzed using sharia maqashid theory. Based on the study conducted, it was concluded that the establishment of the Islamic capital market has shown significant efforts in eliminating the element of gharar in its operations. The existence of a mechanism that all securities entering the sharia capital market flow through strict Islamic JII (Jakarta Islamic Index) selection is now the Indonesian Sharia Stock Index (ISSI) also helping to operate in the Islamic capital market. This institution is a prerequisite, Islamic securities with the main business that is not contrary to Islamic law
\end{abstract}

Keywords: Islamic Capital Market, Islamic Law, Maqoshid sharia 
Volume: 2

Number: 2

Page : $166-178$
E-ISSN:

2655-1942

Terbitan: Oktober 2019

\section{A. Pendahuluan}

Menggeliatnya dunia lembaga-lembaga ekonomi keuangan yang berlebel "syariah" di seluruh penjuru belahan dunia, termasuk Indonesia, merupakan gejala mulai munculnya kembali nilai-nilai Islam yang selama beberapa abad terkubur dan terpendam dalam realitas perekonomian modern. Dalam terminologi hukum Islam, gejala ini merupakan bukti kebangkitan kembali hukum Islam.

Terbukanya sistem perekonomian dunia terhadap nilai-nilai alternatif merupakan jawaban atas persoalan perekonomian modern yang mutlak bersifat meterialistik. Perekonomian yang hanya berdimensi material ternyata tidak dapat memenuhi hasrat kemanusiaan yang berketuhanan. Perekonomian yang secara riil bertujuan untuk memenuhi kebutuhan material, ternyata tidak semata-mata bersifat materialistik. Perekonomian yang bersifat pemenuhan kebutuhan yang bersifat materi ternyata tidak dapat memenuhi kebutuhan manusia yang masih mengakui adanya Tuhan.

Secara hukum, kebutuhan akan nilai-nilai ketuhanan dalam perekonomian modern khususnya dalam dunia keuangan, tentu saja memerlukan dua pendekatan yang harus dilakukan secara sinergis, yaitu pendekatan kemanusiaan yang berketuhanan. Pendekatan kemanusiaan adalah pendekatan yang melihat perekonomian keuangan sebagai kebutuhan manusia sesuai dengan realitas kehidupan yang harus dipenuhi. Sedangkan pendekatan Ketuhanan adalah pendekatan bahwa Tuhan adalah pencipta, pengatur dan pemelihara dari semua apa yang ada di mikro kosmos dan makro kosmos. Pendekatan inilah yang akan digunakan dalam makalah singkat yang membahas transaksi pasar modal syariah dalam perspektif hukum Islam di bawah ini. 
Volume: 2

Number: 2

Page : 166-178
E-ISSN:

2655-1942

Terbitan: Oktober 2019

\section{B. Pembahasan}

\section{Saham}

Saham adalah surat berharga yang diterbitkan oleh sebuah perusahaan saham patungan sebagai instrument untuk meningkatkan modal jangka panjang. Para pemegang saham dari sebuah perusahaan pemilik-pemilik yang disahkan secara hukum dan berhak untuk mendapatkan keuntungan yang diperoleh perusahan dalam bentuk deviden. Dalam pengertiannya yang demikian, maka dalam perspektif hukum Islam dapat ditentukan sebagai berikut;

Dalam perspektif legal theory of Islamic law, saham merupakan urusan manusia dalam memenuhi kebutuhan. Dalam kaitannya dengan ini maka al-Qur'an dan Hadis tidak menentukan pranata-pranata yang berkait dengan urusan manusia dalam memenuhi kebutuhan. Tidak ada teks-teks al-Qur'an dan Hadis yang secara langsung menentukan dan mengatur secara hukum tentang urusan manusia, termasuk saham. Oleh karena itu mencari ketentuan hukum tentang saham di dalam al-Qur'an dan Hadis hanya bersifat secara tidak langsung melalui pemahaman secara (dzan) dugaan. Tidak ada teks yang secara khusus (Qoth'i) tentang saham. Ketentuanketentuan hukum di bidang ekonomi dan keuangan yang ada di dalam al-Qur'an dan Hadis hanyalah dalam ranah ibadah, seperti zakat, infaq dan shadaqah. Dengan logika hukum yang demikian maka di dalam legal theory of Islamic law dirumuskan bahwa sebaga sesuatu dalam bidang ibadah adalah boleh, kecuali yang dilarang secara langsung dan tegas (qoth'i) di dalam al-Qur'an dan Hadis. ${ }^{1}$

Saham merupakan surat berharga yang menunjukkan adanya unsur kepemilikan, maka penerbitan saham tidak boleh dilakukan dalam bentuk

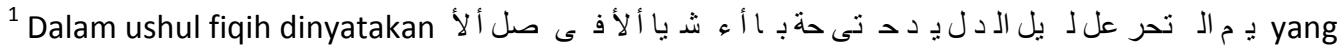
artinya pada dasarnya segala sesuatu adalah boleh sampai ada dalil yang melangnya.
} 
Volume: 2

Number: 2

Page : 166-178
E-ISSN:

$2655-1942$

Terbitan: Oktober 2019

"pengakuan utang" oleh suatu perusahaan. Penerbitan saham tidak boleh dalam bentuk utang piutang. Sebab dalam terminologi hukum Islam terdapat pembedaan nilai suatu harta dalam ranah bisnis (tijarah) dan ranah sosial kebajikan (tabarru"). Di dalam hukum Islam harta tidak hanya bernilai dan berfungsi ekonomis semata tetapi juga mempunyai nilai dan berfungsi sosial. Para ahli hukum Islam menempatkan utang-piutang pada ranah perbuatan kebaikan. Maka secara falsafah hukum Islam, utang piutang hanya diperbolehkan dalam kaitannya dengan pelaksanaan fungsi sosial dari harta. Utang piutang tidak boleh dilakukan dengan motif dan tujuan untuk memperoleh keuntungan. Dengan demikian pranata hukum utang piutang tidak boleh digunakan sebagai instrumen untuk mencari keuntungan. Berdasarkan logika inilah maka di dalam sebuah hadis rasul menyatakan bahwa setiap tambahan (apapun bentuknya) dari sebuah utang piutang adalah riba. ${ }^{2}$

Cara berfikir yang memisahkan fungsi ekonomis dan fungsi social seperti inilah yang sekarang sangat sulit diterapkan dalam kehidupan manusia yang sangat materialistik, konsumtif dan hedonis. Manusia dengan begitu mudahnya disodori fasilitas utang yang luar biasa. Bahkan orang tidak mencari utang tetapi utang masuk ke rumah-rumah. Utang sudah dirasakan sebagai sebuah kebutuhan manusia yang katanya modern. Utang sudah menjadi gaya hidup masyarakat, buktinya ? kartu kredit merupakan gaya hidup. Makin tinggi kebolehan untuk berhutang melalui kartu kredit makin dihargai dan makin tinggi gaya hidupnya. Dalam perspektif hukum Islam, hal ini sangat mengkhawatirkan.

Hal ini perlu sekali ditegaskan dan digarisbawahi karena pranata utangpiutang ini merupakan pranata yang sangat familier. Sosiologis pranata "utang piutang" merupakan pranata yang "sangat praktis, efektif dan efisien untuk memenuhi kebutuhan apapun dan dimanapun baik untuk kepentingan yang bersifat konsumtif

\footnotetext{
2 Di dalah Hadis dinyatakan رب اف هو دذ فعة جر ض قر كل :ص ص الله ر سو قل :ق ل هلي عن artinya: Dari Ali ia berkata: telah bersabda rasulullah saw: Tiap-tiap hutang yang menarik tambahan, adalah riba
} 
Volume: 2

Number: 2

Page : 166-178
E-ISSN:

2655-1942

Terbitan: Oktober 2019

maupun produktif. Perlu segera disadari bahwa pranata utang-piutang merupakan pranata produk sistem ekonomi kapitalis yang menghadap-hadapkan antara orang yang mempunyai kapital dengan orang yang tidak mempunyai kapital sedemikian mutlak tanpa melihat fungsi sosial dari kapital.

\section{Jual beli saham}

Jual beli merupakan pranata hukum yang secara tegas ditentukan di dalam alQur-an maupun di dalam Hadis. Tetapi perlu segera dijelaskan bahwa ketentuan tentang jual beli di dalam al-qur'an hanyalah "pengakuan" akan realitas interaksi antar manusia dalam memenuhi kebutuhannya. Oleh karena itu semua ahli hukum Islam sepakat bahwa dasar ketentuan (nash) tentang jual beli di dalam al-Qur'an bersifat umum. Artinya jual beli dalam bidang apapun, dengan siapapun, dimanapun mendapatkan legalisasi al-Qur'an, kecuali yang secara tegas dilarang. Oleh karena itu secara umum dapat dinyatakan bahwa jual beli saham adalah boleh dalam pengertian tidak dilarang menurut hukum Islam.

\section{Pasar modal}

Dalam Pasal 1 huruf (13) Undang-undang No. 8 tahun 1995 tentang Pasar modal dinyatakan bahwa Pasar Modal adalah kegiatan yang bersangkutan dengan Penawaran Umum dan perdagangan Efek, Perusahaan Publik yang berkaitan dengan Efek yang diterbitkannya, serta lembaga dan profesi yang berkaitan dengan Efek. Pasar modal merupakan kebutuhan riil yang mempunyai banyak kamanfaatan.

a. Pasar modal membuka pasar tetap yang mempermudah para pembeli dan penjual saling bertemu untuk melakukann transaksi.

b. Pasar modal mempermudah pendanaan perusahaan dan perdagangan dan proyek pemerintah melalui penjualan saham dan kertas berharga lain. 
Volume: 2

Number: 2

Page : 166-178
E-ISSN:

2655-1942

Terbitan: Oktober 2019

c. Pasar modal mempermudah dalam mengetahui harga saham maupun surat berharga lainnya dalam penawaran dan permintaan yang bersifat terbuka.

d. Pasar modal memperludah jual beli saham dan surat berharga lainnya bagi yang membutuhkannya.

Walaupun banyak mengandung unsur kemanfaatan, tetapi dalam kenyataannya banyak menimbulkan persoalan dalam perspektif hukum Islam,

a. Kebanyakan jual beli di pasar saham adalah jual beli yang menurut hukum Islam bukan merupakan jual beli yang sesungguhnya, karena tidak ada serah terima saham yang dijualbelikan. Jual beli yang demikian menurut hukum Islam dilarang karena berpotensi menimbulkan jual beli berantai yang semu.

b. Kebanyakan jual beli saham di pasar saham adalah jual beli saham yang belum dimiliki. Ini dilarang oleh hukum Islam karena menjual sesuatu yang belum atau tidak dimiliki mengandung potensi tidak adanya penyerahan saham yang dibeli. Tidak dapat dikategorikan sebagai jual beli as-salam karena saham yang diberi belum dibayar.

c. Harga-harga saham dan surat berharga lain dalam pasar modal tidak sepenuhnya dikondisikan oleh mekanisme pasar. Para pemodal besar dapat mempermainkan secara monopolistis sehingga menguasai pasar dengan cara menjual sahamnya secara besar-besaran sehingga mengkondisikan pemegang saham sejenis menjual saham dengan harga yang murah. Setelah harga murah melakukan pembelian besar-besaran. Ini akan merugikan investor kecil. Demikian juga para pengamat pasar modal sedemikian mudah dapat membawa pengaruh perubaha harga yang tidak menunjukkan mekanisme pasar yang sebenarmya. .

Dari pengertian yang diberikan oleh Undang-undang tersebut maka, Pasar modal Syariah adalah pasar modal yang tidak bertentangan dengan Syariah. Pasar modal adalah sebuah aktivitas perdagangan modal, maka untuk mengetahui transaksi 
Volume: 2

Number: 2

Page : $166-178$
E-ISSN:

$2655-1942$

Terbitan: Oktober 2019

mana yang bertentangan dengan Syariah dan Transaksi mana yang tidak bertentangan dengan syariah tidak dapat dijelaskan secara umum, tetapi melalui proses kajian kasus demi kasus dalam transaksi perdagangan saham. Oleh karena itu hanya transaksi yang berkaitan dengan yang dilarang oleh Syariah saja yang tidak boleh dilakukan, sedangkan transaksi yang tidak dilarang tetap boleh dilakukan.

Transaksi yang dilarang adalah yang berkaitan dengan dzat maupun berkaitan dengan proses. Larangan yang berkaitan dengan dzat misalnya saham-saham yang berhubungan secara langsung dan tidak lagsung dengan dzat yang dilarang, misalnya saham-yang berhubungan dengan babi, khamr, dan dzat yang merugikan lainnya seperti rokok, narkoba. Sedangkan larangan yang berkaitan dengan proses menyangkut;

a. Larangan jual beli saham yang mengandung unsur riba, misalnya saham bank-bank konvensional. ${ }^{3}$

b. Larangan jual beli barang yang tidak dapat diserahkan baik secara langsung maupun simbolis.

c. Larangan melakukan penawaran palsu (bai' an-Najsy) ${ }^{4}$

d. Larangan menjual saham yang belum dimiliki (bai'u al-ma'dum)

e. Larangan jual beli saham yang mengandung unsur judi (maysir/gambling) yang terjadi dalam short selling. ${ }^{5}$

f. Larangan ketidak jelasan jual beli karena ketidakjelasan data (unsur gharar).

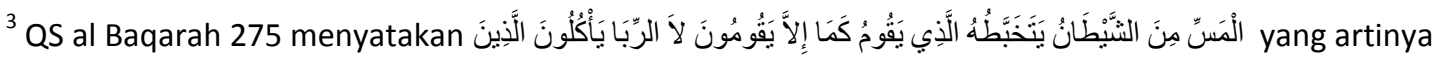
Orang-orang yang makan (mengambil) riba tidak dapat berdiri melainkan seperti berdirinya orang yang kemasukan syaitan lantaran (tekanan) penyakit gila ${ }^{4}$ Jual beli najasy adalah jual beli yang harganya ditinggikan terlebih dahulu sebelum terjadi transaksi sehingga dapat menipu calon pembeli

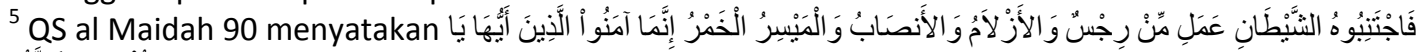

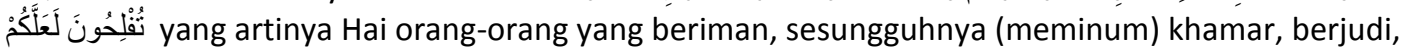
(berkorban untuk) berhala, mengundi nasib (judi) dengan panah, adalah termasuk perbuatan syaitan. Maka jauhilah perbuatan-perbuatan itu agar kamu mendapat keberuntungan
} 
Volume: 2

Number: 2

Page : 166-178
E-ISSN:

$2655-1942$

Terbitan: Oktober 2019

g. Larangan jual beli saham yang berkait dengan penipuan data. Menyebarluaskan informasi yang menyesatkan untuk memperoleh keuntungan transaksi yang dilarang.

h. Larangan pemaksaan dalam jual beli.

i. Insider trading, yaitu memakai informasi orang dalam untuk memperoleh keuntungan transaksi yang dilarang.

j. Margin trading, yaitu melakukan transaksi atas Efek dengan fasilitas pinjaman atas kewajiban penyelesaian pembelian Efek.

k. Ihtikar (larangan monopoli), yaitu melakukan pembelian atau dan pengumpulan suatu Efek yang menyebabkan perubahan harga Efek, dengan tujuan mempengaruhi Pihak lain.

Dalam merespon praktek perdagangan saham, Lembaga pengkajian Ilmu hukum Islam (fiqih) yang tergabung dalam Rabithah al-Alam al-Islami pada tahun 1414 H di Mekah menentukan bahwa. ${ }^{6}$

a. Bahwa pasar modal mengandung unsur kemaslahatan, tetapi dalam praktek memunculkan persoalan persoalan yang berkaitan dengan perjudian dan potensi memanfaatkan ketidaktahuan orang yang berpotensi dhalim, yang perlu ditentukan secara kasus perkasus.

b. Pedagang saham tidak dapat menjual saham-saham yang belum ada dalam kepemilikannya, kecuali dengan jual as-salam dengan syarat dan rukun yang harus terpenuhi. Jual beli saham yang belum ada dalam kepemilikannya ini terus berlaku secara berantai sehingga siapa yang menjual dan siapa yang membeli tidak diketahui, sehingga sifatnya betukbetul spekulatif sehingga mengandung unsur judi yang dilarang oleh hukum Islam.

\footnotetext{
${ }^{6}$ Abdullah al-Mushlih dan shalah ash-Shawi Fiqih Ekonomi Keuangan Islam, terjemahan Abu Umar Basyir. (Jakarta: Darul Haq, 2004)
} 
Volume: 2

Number: 2

Page : $166-178$
E-ISSN:

2655-1942

Terbitan: Oktober 2019

c. Jual beli saham tidak boleh terhadap saham-saham yang mengandung unsur riba. ${ }^{7}$

d. Jual beli saham tidak boleh terhadap saham-saham yang dengan yang haram karena dzatnya. ${ }^{8}$

Untuk menjaga pasar modal tetap dalam kerangka syariah maka metwally memberikan karakteristik operasional bagi pasar modal Syariah sebagai berikut: ${ }^{9}$

a. Semua saham harus diperjualbelikan pada bursa efek

b. Bursa perlu mempersiapkan pasca perdagangan dimana saham dapat diperjualbelikan melalui pialang

c. Semua perusahaan yang mempunyai saham yang dapat diperjualbelikan di Bursa efek diminta menyampaikan informasi tentang perhitungan (account) keuntungan dan kerugian serta neraca keuntungan kepada komite manajemen bursa efek, dengan jarak tidak lebih dari 3 bulan.

d. Komite manajemen menerapkan harga saham tertinggi (HST) tiaptiap perusahaan dengan interval tidak lebih dari 3 bulan sekali.

e. Saham tidak boleh diperjual belikan dengan harga lebih tinggi dari HST.

f. Saham dapat dijual dengan harga dibawah HST.

g. Komite manajemen harus memastikan bahwa semua perusahaan yang terlibat dalam bursa efek itu mengikuti standar akuntansi syariah.

h. Perdagangan saham mestinya hanya berlangsung dalam satu minggu periode perdagangan setelah menentukan HST.

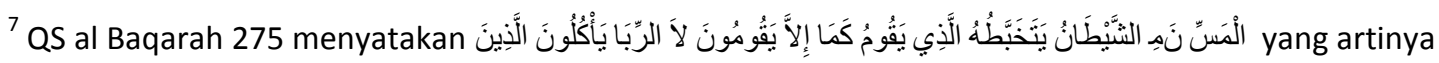
Orang-orang yang makan (mengambil) riba tidak dapat berdiri melainkan seperti berdirinya orang yang kemasukan syaitan lantaran (tekanan) penyakit gila

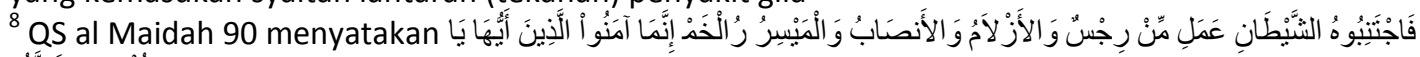

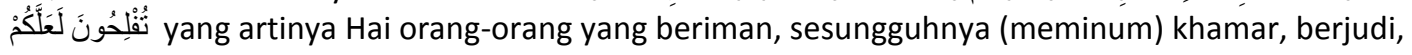
(berkorban untuk) berhala, mengundi nasib (judi) dengan panah, adalah termasuk perbuatan syaitan. Maka jauhilah perbuatan-perbuatan itu agar kamu mendapat keberuntungan

${ }^{9}$ Metwally, 1995, halaman 178-179 
Volume: 2

Number: 2

Page : $166-178$
E-ISSN:

2655-1942

Terbitan: Oktober 2019

i. Perusahaan hanya dapat menerbitkan saham baru dalam periode perdagangan, dan dengan harga HS

\section{Kriteria Pasar Modal Syariah}

Dalam Negara Islam, hukum Islam dapat berlaku lebih efektif, karena kekuasaan Negara secara langsung mempunyai hak kontrol terhadap berlakunya hukum Islam. Sedangkan di dalam negara yang bukan Negara Islam atau tidak berdasarkan pada ideologi Islam seperti Indonesia, berlakunya hukum Islam mendasarkan pada kultur, sehingga Negara relatif tidak mempunyai ruh yang memberikan semangat untuk mengawasi berlakunya hukum Islam, kecuali sebatas hukum Islam yang sudah diformalkan menjadi bagian hukum Negara. Inipun sangat formalistik sifatnya.

Penerapan hukum Islam dalam dunia ekonomi bisnis keuangan terhambat oleh problem struktur yang harus mendasarkan pada kultur. Persoalan ini terus berantai yang menjadikan penerapan hukum ekonomi bisnis Islam dalam dunia keuangan bercampur dengan yang tidak Islam. Artinya lembaga-lembaga keuangan yang menyatakan diri sebagai "Syariah" belum dapat menerapkan Syariah secara murni. Dalam dunia perbankan misalnya, secara struktural bank-bank Syariah tidak bisa melepaskan diri sepenuhnya dari bank Indonesia yang bersistem bunga. Secara kultural bungan masih manjadi ruh dalam menerapkan hukum Islam. Ruhnya justru bukan hukum Islam. Demikian juga dalam dunia pasar modal ruhnya belum sepenuhnya didasarkan pada ruh Islam, tetapi masih bercampur dengan ruh non Islam.

Meskipun secara kultural Dewan Syariah Nasional Majlis Ulama Indonesia telah membangun sistem sedemikian rupa dalam usaha menerapkan hukum Islam dalam dunia ekonomi keuangan, termasuk dalam kaitannya dengan pasar modal, 


\section{Law, Development \& Justice Review}

\begin{tabular}{llrr}
\hline \hline Volume: & 2 & E-ISSN: & $2655-1942$ \\
Number: & 2 & Terbitan: & Oktober 2019 \\
Page : & $166-178$ & & \\
\hline
\end{tabular}

namun karena hanya dalam bentuk fatwa, ${ }^{10}$ maka sifatnya sangat normatif, sehingga secaa sosiologis pelaksanaannya masih sangat tergantung pada kekuasaan. Hal ini dapat dilihat dengan mudah dilihat dalam Keputusan Ketua Badan Pengawas Pasar Modal dan Lembaga Keuangan Nomor: Kep-208/BL/201 yang mengkategorikan perusahaan yang melaksanakan sebagian transaksi yang dilarang oleh Syariah dikategorikan sebagai perusahaan yang tidak bertentangan dengan syariah. ${ }^{11}$ Ini berarti mencampuradukkan antara yang hak dan yang batil. ${ }^{12}$

10 Fatwa-fatwa DSN-MUI yang berkait dengan pasar modal yaitu: Fatwa Nomor: 80/DSN-MUI/III/2011 tentang Penerapan Prinsip Syariah dalam Mekanisme Perdagangan Efek Bersifat Ekuitas Di Pasar Reguler Bursa Efek Fatwa Nomor: 76/DSN-MUI/VI/2010 tentang SBSN Ijarah Asset To Be Leased Fatwa Nomor: 72/DSN-MUI/VI/2008 tentang Surat Berharga Syariah Negara ljarah Sale and Lease Back

Fatwa Nomor: 71/DSN-MUI/VI/2008 tentang Sale and Lease Back

Fatwa Nomor: 70/DSN-MUI/VI/2008 tentang Metode Penerbitan Surat Berharga Syariah Negara Fatwa Nomor: 69/DSN-MUI/VI/2008 tentang Surat Berharga Syariah Negara

Fatwa Nomor: 66/DSN-MUI/III/2008 tentang Waran Syariah

Fatwa Nomor: 65/DSN-MUI/III/2008 tentang Hak Memesan Efek Terlebih Dahulu Syariah (HMETD Syariah)

Fatwa Nomor: 59/DSN-MUI/V/2007 tentang Obligasi Syariah Mudharabah Konversi Fatwa Nomor: 50/DSN-MUI/III/2006 tentang Akad Mudharabah Musytarakah Fatwa Nomor: 41/DSN-MUI/III/2004 tentang Obligasi Syariah ljarah Fatwa Nomor: 40/DSN-MUI/X/2003 tentang Pasar Modal dan Pedoman Umum Penerapan Prinsip Syariah di Bidang Pasar Modal

Fatwa Nomor: 33/DSN-MUI/IX/2002 tentang Obligasi Syariah Mudharabah

Fatwa Nomor: 32/DSN-MUI/IX/2002 tentang Obligasi Syariah

Fatwa Nomor: 20/DSN-MUI/IV/2001 tentang Pedoman Pelaksanaan Investasi Untuk Reksa Dana Syariah

Fatwa Nomor: 11/DSN-MUI/IV/2000 tentang Kafalah

Fatwa Nomor: 10/DSN-MUI/IV/2000 tentang Wakalah

Fatwa Nomor: 09/DSN-MUI/IV/2000 tentang Pembiayaan ljarah

Fatwa Nomor: 08/DSN-MUI/IV/2000 tentang Pembiayaan Musyarakah

Fatwa Nomor: 07/DSN-MUI/IV/2000 tentang Pembiayaan Mudharabah (Qiradh)

${ }_{11}$ Efek yang dapat dimuat dalam daftar efek syariah ditentukan sebagai (a) Emiten dan Perusahaan Publik yang secara jelas menyatakan dalam anggaran dasarnya bahwa kegiatan usaha Emiten dan Perusahaan Publik tidak bertentangan dengan Prinsip-prinsip syariah.; (b) Emiten dan Perusahaan Publik yang tidak menyatakan dalam anggaran dasarnya bahwa kegiatan usaha Emiten dan Perusahaan Publik tidak bertentangan dengan Prinsip-prinsip syariah, namun memenuhi kriteria antara lain emiten dan perusahaan yang (1) rasio total hutang berbasis bunga dibandingkan total ekuitas tidak lebih dari $82 \%$, dan (2) rasio total pendapatan bunga dan total pendapatan tidak halal lainnya dibandingkan total pendapatan usaha dan total pendapatan lainnya tidak lebih dari $10 \%$. Di 


\section{Law, Development \& Justice Review}

Volume: 2

Number: 2

Page : $166-178$
E-ISSN:

$2655-1942$

Terbitan: Oktober 2019

\section{Kesimpulan}

Pasar Modal Syariah adalah pasar modal yang berdasarkan Syariah Islam. Penggunaan kata "Syariah" mengandung nilai religius yang tanggung jawabnya tidak hanya kepada manusia yang membutuhkan, tetapi jauh tanggung jawabnya kepada Tuhan. Meskipun sekarang masih boleh dikategorikan sebagai sebuah proses, namun harus jelas orientasinya kepada syariah murni. Dengan demikian ukuran Syariah bukan hanya terletak pada nama, tetapi justru adalah substansinya. Maka peruhaan publik dan emiten yang melakukan usaha yang dilarang oleh syariah tidak boleh dikategorikan sebagai Syariah

Pelaksana negara tidak boleh sekedar menarik keuntungan dari label-label syariah tanpa kontrol yang ketat tentang kemurnian syariahnya. Oleh karena itu negara Indonesia harus melindungi warga negaranya yang mayoritas muslim untuk bersyariah secara benar. Wallahu a'lam bi-ashowwab.

dalam lampiran Keputusan Ketua Bapepam dan LK Nomor : Kep-208/BL/2012 Tanggal : 24 April 201 juga dinyatakan: bahwa efek yang diterbitkan oleh emiten atau perusahaan publik yang tidak menyatakan diri syariah dapat dikategorikan sebagai Syariah jika memenuhi rasio-rasio keuangan sebagai berikut:: (1) total utang yang berbasis bunga dibandingkan dengan total aset tidak lebih dari 45\% (empat puluh lima per seratus); atau (2) total pendapatan bunga dan pendapatan tidak halal lainnya dibandingkan dengan total pendapatan usaha (revenue) dan pendapatan lain-lain tidak lebih dari $10 \%$ (sepuluh per seratus);

${ }^{12}$ QS al Baqarah 42 menyatakan بِالْبَاطِلِ الْحَقَ تَلْبِسُو أوَلاَ (jangan mencampuradukkan yang hak dengan yang batil). 


\section{Law, Development \& Justice Review}

Volume: 2

Number: 2

Page : $166-178$

\section{E-ISSN:}

Terbitan: Oktober 2019

\section{DAFTAR PUSTAKA}

Huda Nurul dan Edwin Nasution Mustafa. "Investasi Pada Pasar Modal Syariah". Jakarta: Kencana, 2008.

Huda Nurul dan Heykal Mohamad. "Lembaga Keuangan Islam, Tinjauan Teoretis dan Praktis”. Jakarta: Kencana, 2010.

Soemitra Andri. “Bank dan Lembaga Keuangan Syari’ah”. Jakarta: Kencana, 2010.

Sutedi Adrian. "Pasar Modal Syariah Sarana Investasi Keuangan Berdasarkan Prinsip Syariah”. Jakarta: Sinar Grafika, 2014.

Yusuf Muhammad. "Manajemen Keuangan Syariah". Mataram: Penerbit Institut Agama Islam Negeri (IAIN) Mataram, 2015. 